\title{
Acting against obesity: a cross-cultural analysis of prevention models in Spain, Argentina and Brazil
}

\author{
Mabel Gracia-Arnaiz \\ Universitat Rovira i Virgili
}

Flavia Demonte

Universidad Nacional de San Martin

Fabiana Bom Kraemer ( $\nabla$ fabianabkraemer@gmail.com )

Universidade do Estado do Rio de Janeiro https://orcid.org/0000-0002-3305-3358

\section{Research article}

Keywords: obesity, health policies, preventive model, social inequality, cross-cultural analysis

Posted Date: May 6th, 2020

DOl: https://doi.org/10.21203/rs.3.rs-25986/v1

License: (1) This work is licensed under a Creative Commons Attribution 4.0 International License. Read Full License

Version of Record: A version of this preprint was published at Critical Reviews in Food Science and Nutrition on December 16th, 2020. See the published version at https://doi.org/10.1080/10408398.2020.1852169. 


\title{
TITLE PAGE
}

\section{Acting against obesity: a cross-cultural analysis of prevention models in Spain, Argentina and Brazil}

\author{
Mabel Gracia-Arnaiz, Universitat Rovira i Virgili (Tarragone, Spain) \\ Flavia Demonte, National Scientific and Technical Research Council (CONICET)/National University \\ of San Martín (UNSAM, San Martín District, Argentina) \\ Fabiana Bom Kraemer, Universidade do Estado do Rio de Janeiro (UERJ, Brazil) \\ Corresponding author: \\ Correspondence concerning this article should be addressed to Dr. Fabiana Bom Kraemer, \\ Universidade do Estado do Rio de Janeiro, Instituto de Nutrição, Rua São Francisco Xavier, 524, \\ $12^{\circ}$. Andar, sala12007 BI. E. Maracanã, Rio de Janeiro, RJ, Brasil. CEP: 20550-900. \\ Contact: fkraemer@uerj.br
}

Contact details

Mabel Gracia-Arnaiz: Mabel.gracia@urv.cat

Av. Catalunya, 35. 43002 Tarragona, Spain

Telephone: +34 977559771

Flavia Demonte flaviademonte@gmail.com

Av. 25 de Mayo \& Francia, San Martín, Buenos Aires, Argentina. CP: 1650

Telephone: +54 11 4006-1500 ext. 1032/1033/1034

Fabiana Bom Kraemer: fkraemer@uerj.br

Rua São Francisco Xavier, 524, 12ํ․ Andar, sala12007 BI. E. Maracanã, Rio de Janeiro, RJ, Brasil. CEP: 20550-900.

Telephone: +55 2123340679 Rm 220

\section{Biographical statement}

Dr. Mabel Gracia-Arnaiz

Ph.D. in Social Anthropology and professor of the Universitat Rovira i Virgili (Tarragona, Spain). Her research interests are focused on the sociocultural study of food, gender and health. Spain and Mexico are her ethnographic areas of specialization and in these places she has conducted qualitative research on various national and international projects. She has been visiting scholar at Edgar Morin Centre (CNRS, Paris), CIESAS (Ciudad de Mexico) and the Food Studies Centre of SOAS (University of London), among other research centers. The results of her work have been published in numerous books, books chapters. Some of them are available at https://www.researchgate.net/profile/Mabel_Gracia-Arnaiz.

\section{Dr. Flavia Demonte}

Ph.D. in Social Sciences. Researcher at the National Scientific and Technical

Research Council (CONICET-UNSAM, Argentina). Professor of the National University of San Martín (UNSAM, San Martín, Argentina). Professor of the Nacional University of La Plata (UNLP, La Plata, Argentina). Her research interests are focused on the sociocultural study of food and health.

Some of results of her work are available at http://investigadores.unsam.edu.ar/es/investigador/535/Demonte-Flavia-Carolina

\section{Dr. Fabiana Bom Kraemer}

Ph.D. in Sciences and Professor at the Graduate Program in Food, Nutrition and Health (PPG-ANS) at the Nutrition Institute at Rio de Janeiro State University (UERJ). Researcher at the Center for the Study of Food and Culture (NECTAR, UERJ) and leader of the research group LADIGE Digital Laboratory of Food Education and Humanities (Federal University of Rio de Janeiro, UFRJ). Currently, I am academic coordinator at the PPG-ANS, UERJ. 
Acting against obesity: a cross-cultural analysis of prevention models in Spain, Argentina and Brazil

\begin{abstract}
Background:

In contexts where prevalence of obesity has increased rapidly, sociocultural causes acquire greater explanatory power as opposed to biological and/or behavioural factors. These models premise worsening diets and sedentary lifestyles as being the main culprits and assume that contemporary societies generate obesogenic and toxic environments. This article analyses and compares preventive models for obesity in Spain, Argentina and Brazil through an examination of the respective measures adopted to counter it in those countries. The primary aim is to delineate the conceptual framework and reflect on the reasons for their relative effectiveness.
\end{abstract}

\title{
Methods:
}

This qualitative study is based on the content analysis of programmes developed by the Spanish, Argentinian and Brazilian health authorities to deal with obesity from 2005 to the present. The texts have been carefully collated by accessing the health ministry websites classifying them according to subject, year of publication and implementation, their specific objectives and proposals for action. A total of 46 documents were selected during 2017-19. In a complementary way, statistical sources have been used in order to better understand changes in living conditions and health.

\section{Results:}

Over the last fifteen years, the international health bodies have developed specific strategies to control and prevent obesity based on a global diagnosis, whose features have been supported by these three countries. Although the measures reflect certain particularities, they conform to a common pattern organised from platforms promoting so-called "healthy 
lifestyles" for all. Most of the measures taken have minimized consideration of the social determinants of health, ignoring that epidemiological sources and statistics indicate that obesity rates have increased most quickly among individuals of low socioeconomic status during this period. In general, the responses have been formulated without further research into the different dimensions of obesity, either because they have been short-term, not based on diagnoses adjusted to each context.

\section{Conclusions:}

The discussion suggests that the excessive emphasis on individual responsibility and the underplaying of the role of food as a complex practice, as well as changing structural factors and the differential distribution of this disease, might largely explain the limited impact of these strategies.

Key words: food; obesity; health policies; preventive model; social inequality; cross-cultural analysis.

\section{Introduction}

Health policies to prevent and control obesity have been implemented across the world in the last couple of decades since the World Health Organisation declared it the noncommunicable global epidemic of the 21st century (WHO, 2000). The organisation points out that its prevalence almost tripled from 1975 to 2016, highlighting that one in eight adults is now obese. No less worrying than the obesity rates among the adult population are the comparably growing numbers of overweight or obese children and adolescents (WHO, 2019). While the rise of this condition has been most significant in north American countries, it is a growing cause for concern in south American countries such as Argentina and Brazil (Jiwani et al., 2019) - and also European ones such as Spain (Hernáez et al., 2019). There is a broad consensus in the biomedical literature on classifying obesity as a chronic noncommunicable disease (CNCD), associating it with diabetes, cardiovascular disorders and 
different types of cancer, and seeing it as the result of biological, behavioural and cultural factors (Swinburn et al., 1999). However, given the difficulties associated with its treatment (Bray \& Tartaglia, 2000) and its growing prevalence worldwide (Dinsa, 2012; Ng et al., 2014), environmental factors have come to the fore, playing a strategic role in the definition of the problem and the interventions proposed. Its rise is seen as a global phenomenon caused by the profound technological, demographic and socioeconomic transformations that have taken place on a planetary scale. It is considered to be a direct consequence of hypercaloric diets due to increased consumption of ultra-processed food and of insufficient energy expenditure as the ultimate expression of both the current agroindustrial food system and the mechanisation of daily life (Popkin \& Gordon-Larsen, 2004).This has led health professionals to describe contemporary societies as 'obesogenic' or environmentally 'toxic' (Brownell \& Horgen, 2003).

The aim of this comparative analysis is to delineate the conceptual framework of the preventive models implemented in recent years in Spain, Argentina and Brazil and to reflect on the reasons for their relative effectiveness. Its starting point is 2004 , as that is when the WHO Global Strategy on Diet, Physical Activity and Health (DPAS, 2004) first appeared. Also considered is the Pan-American Health Organisation's (PAHO) Regional Strategy and Plan of Action for an Integrated Approach to the Prevention and Control of Chronic Diseases, including Diet, Physical Activity and Health (2007), which urges all member states to develop policies on non-communicable diseases, including obesity.

Despite the disparate socioeconomic and political contexts represented by the three countries, there are shared elements that have facilitated comparison. The sustained rise in the prevalence of obesity coincides, paradoxically, with the increased application of diagnostic and clinical treatment protocols, with the running of numerous preventive campaigns, with the spread of lipophobia and social stigmatisation of fatness - and also in a context where their respective populations have a better understanding of the relationship 
between food and health. On the other hand, most of the public policies have been formulated and implemented concomitantly with the experience of the recent economic crises, which have, at different times and with specific consequences, affected the most socially vulnerable sections of the population. Starting from the observation that the measures adopted have so far failed to curb and/or reverse the prevalence of obesity, we wonder if this is related to the conceptual structure of the preventive models itself, which, while emphasising the importance of environment, has placed excessive emphasis on individual responsibility, overlooking food as a complex practice, superficially highlighting certain structural factors and relegating the unequal social distribution of obesity to the status of a secondary consideration.

\section{Materials and methods}

Forming part of a broader study, ${ }^{1}$ this article qualitatively analyses the main documents published by the governments of Spain, Argentina and Brazil detailing their policies for tackling obesity. Although the strategies developed by the $\mathrm{WHO}$ and its regional offices for Europe and Latin America have also been considered (a total of 17 documents sourced from their websites), the focus has mainly been on state actions under the Strategy for Nutrition, Physical Activity and Prevention of Obesity (Spain) (NAOS, 2005), the National Programme for Healthy Eating and Prevention of Obesity (Argentina) (Ministry of Health, 2016a) and the Intersectoral Strategy for the Control and Prevention of Obesity (Brazil) (CAISAN, 2014). The texts have been carefully collated and selected by accessing the health ministry websites with criteria of theoretical relevance in mind, classifying them according to subject, year of publication and implementation, their specific objectives and proposals for action. The systematisation of the data and the analysis took place during 2017-19 based on a total of 46 documents that met the requirements for inclusion (Table 1) and were distributed thus: 22 (Spain), 13 (Argentina) and 11 (Brazil). 


\section{Table 1}

Criteria for inclusion and exclusion of the documents acquired

\begin{tabular}{|c|c|}
\hline Inclusion criteria & Exclusion criteria \\
\hline $\begin{array}{ll}\text { - } & \text { Global Action Plan for the Prevention and } \\
\text { - } & \text { Control of CNCD } \\
\text { - } & \text { Global and national strategies on Diet, Physical } \\
\text { - } & \text { Activity and Health } \\
\text { - } & \text { progrional food and nutrition action plans and } \\
\text { - } & \text { Action statements on prevention of obesity } \\
\text { - } & \text { Provisions, regulations, resolutions and laws } \\
\text { - } & \text { related to obesity prevention } \\
\text { - } & \text { Monity indicators and data } \\
\text { - } & \text { Programmes, projects, materials and guides for } \\
\text { the general public }\end{array}$ & $\begin{array}{ll}\text { - } & \text { Health care plan (general) } \\
\text { - } & \text { Recommendations solely referring to specific } \\
\text { - } & \text { food/drink consumption } \\
& \text { Programmes of physical activity or diet for } \\
& \text { camp, retirement homes etc.) and/or regions, } \\
& \text { provinces or municipalities } \\
\text { - } & \text { Research projects } \\
\text { - } & \text { General strategies for promoting health and } \\
\text { - } & \text { preventing disease } \\
\text { - } & \text { Conformation material (such as leaflets) }\end{array}$ \\
\hline
\end{tabular}
Source: author's own work.

The qualitative study of the documents involved following the thematic analysis method (Guest, 2012) using the Atlas.ti v.8 program. After generating the initial codes and linking them to the text fragments, an analysis map was drawn up based on these seven thematic categories or families: obesity as a disease, causality, socioeconomic costs, typology of measures, target groups, areas of intervention and results. This procedure used inductive reasoning, by which the categories and codes, primarily based on textual quotations, emerge from the data through meticulous examination and checking. This systematisation made it possible to create the matrices for qualitative analysis and thus facilitate the comparison, establishing the recurrent and/or contrasting categories between each country's documents. This approach is an inherently interpretative act based on a detailed analysis of the narratives constructed by the government bodies, going beyond the merely descriptive and quantitative goals that are usually pursued in content analysis. The contents of these secondary sources have been analysed as cultural texts (Campbell, 2011) in the sense that they embody the hegemonic discourses and can therefore be considered as the authorised voices that construct the 'reality' (Kleinman, 1988), in this case of obesity. 
Lastly, and in a way that is complementary to the analysis, statistical sources have been used in order to better understand changes in the living conditions and health of these populations during this period. Given the breadth and diversity of the statistical sources, only the survey items of interest for the phenomenon under study have been analysed. This is the case, for example, with unemployment, the general index of the population at risk of poverty and social exclusion, and the prevalence of obesity and overweight. With that in mind, surveys on living conditions (ECV), active population (EPA) and the National Health surveys (ENS 2006, 2012 and 2018) have been consulted for Spain; for Argentina, statistics on poverty and unemployment rate (INDEC), surveys on food insecurity (ODSA-UCA) and the National Surveys of Risk Factors (MS 2006, 2009, 2013 and 2018). Finally, for Brazil, it was the National Household Sample Survey (PNAD), the Family Budget Survey (POF, 2002-2003 y 2008-2009) (IBGE 2004, 2011), the National Health Survey (PNS 2013) (IBGE, 2014) and the telephone survey on Risk Factor Monitoring and Protection against Chronic Diseases (VIGITEL, 2018) (MINISTÉRIO DA SAÚDE, 2019).

\section{Results}

\subsection{Taking measures against obesity: the main actions}

\subsubsection{Weight matters: the global context}

Over 15 years ago, the WHO drew up the Global Strategy on Diet, Physical Activity and Health (DPAS) as an integral tool to guide member states in their efforts to prevent chronic diseases (Gracia-Arnaiz, 2017: 68). Obesity is conceived principally as a disease linked to increased comorbidity and mortality, stemming from 'unhealthy diets, inadequate physical activity' and chiefly the result of 'energy imbalances' (WHO, 2004:4). It is a multifaceted strategy that underscored the significance of the environment responsible for creating so- 
called 'obesogenic' societies. With a principal objective of 'improv[ing] diets and increas[ing] physical activity that are sustainable, comprehensive, and actively engag[ing] all sectors, including civil society, the private sector and the media', the institution encouraged member states to elaborate national, regional and community policies that could focus attention on both individual and social environmental factors as targets for health promotion interventions. Most of the actions undertaken have challenged politicians, business people, educators and health professionals to promote more active and healthy lifestyles from within their respective spheres.

In recent years, the WHO has refocused its recommendations after noticing that the prevalence of obesity has continued to rise concurrently with the first implementation of these prevention-based actions. In response to the recent economic crisis, a new paper referencing the micro-environmental factors shaping dietary patterns (employment, housing, social inequalities) or the macro-environmental factors influencing food consumption (increased food supply, decline of food prices, food corporations, and industrialisation of agriculture) has been published (WHO, 2012:17). In this vein, the WHO European Region Food and Nutrition Action Plan 2015-2020 (WHO, 2015) has focused on the need to act beyond promoting healthy food choices and physical exercise. Obesity is recognised as an inequality issue (WHO, 2014) and universal access to healthy foods proposed, especially for the most vulnerable groups, along with equity and gender equality in relation to nutrition for all European citizens. These objectives have been incorporated into the member institutions' commitments on the eradication of poverty, the improvement of public health and fiscal policies on diet within the framework of the Sustainable Development Goals (UN, 2015). At the heart of the debate is the need to improve food system governance.

For its part, in 2007 the PAHO drew up the Regional Strategy and Action Plan with an Integrated Focus on the Prevention and Control of CNCDs, proposing courses of action for their prevention and treatment. However, by 2012 it was already recognising that while great 
strides had been made, it had not managed to halt the advance of CNCDs. It therefore proposed implementing multisectoral activities while also taking the social determinants of obesity into account. In 2014 it stated that 'the most important factors driving weight gain and obesity (...) are heavy consumption of products with low nutritional value and high sugar, fat and salt content $(\ldots)$, such as "snacks" and fast food (...); the regular intake of sugary drinks and insufficient physical exercise. All these are part of an obesogenic environment' (OPS, 2014:8). For that reason, the PAHO urges member states to implement measures aimed at 'transforming the current obesogenic environment into opportunities to promote greater consumption of nutritious food and an increase in physical activity' (OPS, 2014:17). The main proposals revolve around the promotion of healthy eating, the improvement of school environments, tax policies, and the regulation of advertising and labelling of foodstuffs. In recent years, in line with the WHO and its SDGs (Sustainable Development Goals), the co-existence of malnutrition and obesity in contexts of poverty and inequality has been recognised, with proposals to transform food systems to make them more sustainable and inclusive by means of regulations giving the population access to nutritious, safe and varied products (OPS, 2018).

\section{Table 2}

Relevant international programmes (2004-2018)

\begin{tabular}{lll}
\hline Institution Year Plan & Actions \\
\hline
\end{tabular}




\begin{tabular}{|c|c|c|c|}
\hline \multirow[t]{7}{*}{ WHO } & 2004 & DPAS & Global Strategy on Diet, Physical Activity and Health \\
\hline & 2008 & Action Plan & $\begin{array}{l}2008-2013 \text { Action Plan for the Global Strategy for the } \\
\text { Prevention and Control of Non-communicable Diseases }\end{array}$ \\
\hline & 2012 & Report & Population-based approaches to childhood obesity prevention \\
\hline & 2013 & Plan & $\begin{array}{l}\text { Global Action Plan for the prevention and control of non- } \\
\text { communicable diseases (2013-2020) }\end{array}$ \\
\hline & 2014 & Group & $\begin{array}{l}\text { Commission on Ending Childhood Obesity }(\mathrm{ECHO}) \\
\text { Fiscal policies for diet and the prevention of non- } \\
\text { communicable diseases }\end{array}$ \\
\hline & 2016 & Report & $\begin{array}{l}\text { WHO European Action plan for food and nutrition } \\
\text { policy } 2007-2012 \\
\text { Vienna Declaration on Nutrition and Non-communicable }\end{array}$ \\
\hline & 2008 & Plan & Disease in the Context of Health 2020 \\
\hline \multirow{4}{*}{ WHO-EU } & 2013 & Declaration & Obesity and Inequalities \\
\hline & 2014 & Guidance & European Food and Nutrition Action Plan 2015-2020 \\
\hline & 2015 & Plan & $\begin{array}{l}\text { Mapping the health system response to childhood obesity in } \\
\text { the WHO European Region }\end{array}$ \\
\hline & 2019 & Report & \\
\hline \multirow[t]{6}{*}{ OPS } & 2007 & Strategy & $\begin{array}{l}\text { Regional Strategy and Action Plan for an Integrated Approach } \\
\text { to Prevention and Control of NCDs, including diet, physical } \\
\text { activity and health }\end{array}$ \\
\hline & 2012 & Strategy & Strategy for the prevention and control of NCDs \\
\hline & 2014 & Plan & $\begin{array}{l}\text { Action Plan for the Prevention and Control of NCDs in the } \\
\text { Americas 2013-2019 }\end{array}$ \\
\hline & 2014 & Plan & $\begin{array}{l}\text { Action plan for the prevention of obesity in children and } \\
\text { adolescents }\end{array}$ \\
\hline & 2015 & Report & $\begin{array}{l}\text { Ultra-processed foods and drinks in Latin America: trends, } \\
\text { effect on obesity and implications for public policy }\end{array}$ \\
\hline & 2018 & Report & $\begin{array}{l}\text { Food policies and programmes to prevent overweight and } \\
\text { obesity. Lessons learned. }\end{array}$ \\
\hline
\end{tabular}

Source: author's own research².

\subsubsection{Local strategies: implementing measures}

According to The Global Strategy on Diet, Physical Activity and Health of the WHO (DPAS, 2004) and the PAHO (2007), the starting point for the measures implemented in Spain, Argentina and Brazil (Table 3) is that obesity is an epidemic disease, multicausal and very costly for the health system and society as a whole, but nevertheless avoidable. Based on this premise, each country designs its own strategy for dealing with it, reproducing the diagnosis of its causes and replicating some of the measures proposed at the global level.

\section{Table 3}

Plans, programmes and significant actions in the prevention and control of obesity in Spain, Argentina and Brazil (2005-2018) 


\begin{tabular}{|c|c|c|c|}
\hline Country & Year & $\begin{array}{l}\text { Plan/ } \\
\text { Programme } \\
\text { Law/ }\end{array}$ & Description \\
\hline \multirow[t]{11}{*}{ Spain } & 2005 & NAOS & Strategy for nutrition, physical activity and prevention of obesity \\
\hline & 2005 & PERSEO & Pilot Schools Programme for Healthy Eating and Exercise \\
\hline & 2005 & PAOS & $\begin{array}{l}\text { Co-regulation code for food and drink advertising targeted at children, obesity } \\
\text { prevention and health }\end{array}$ \\
\hline & 2008 & $\begin{array}{l}\text { GUSTINO } \\
\text { Project }\end{array}$ & Programme encouraging restaurants to promote healthy and balanced menus \\
\hline & 2011 & Law & Food Safety and Nutrition Act $17 / 2011$ \\
\hline & 2011 & NAOS & Evaluation and monitoring of the NAOS strategy: minimum set of indicators \\
\hline & 2013 & Fifty-fifty & Programme to improve the overall health of the adult population \\
\hline & 2013 & Observatory & Nutrition Observatory and Study of Obesity \\
\hline & 2014 & JANPA (EU) & European Action Plan on Childhood Obesity, 2014-2020 \\
\hline & 2015 & PANGEI & $\begin{array}{l}\text { Food, Nutrition and Gastronomy Programme for Pre-school Education (PANGEI). } \\
\text { El gusto es mío (The pleasure/taste is mine). }\end{array}$ \\
\hline & 2018 & Plan & Collaboration plan for improving food and drink ingredients and other measures \\
\hline \multirow{10}{*}{$\begin{array}{l}\text { Argenti } \\
\text { na }\end{array}$} & 2008 & Law & Law No. 26396 on Food Disorders \\
\hline & 2009 & Strategy & $\begin{array}{l}\text { Res.1083/09. National Strategy for the Prevention and Control of CNCDs and } \\
\text { Healthy Argentina Plan }\end{array}$ \\
\hline & 2013 & Programme & Res. 578/2013. National Programme to Combat Sedentarism \\
\hline & 2014 & Law & Initiative for a Trans Fat Free Argentina (Food Industry) \\
\hline & 2014 & Guidelines & Clinical Guidelines on the Diagnosis and Treatment of Obesity in Adults \\
\hline & 2015 & $\begin{array}{l}\text { Decree/ } \\
\text { Project }\end{array}$ & $\begin{array}{l}\text { Project for Protecting Vulnerable People against Chronic Non-Communicable } \\
\text { Diseases }\end{array}$ \\
\hline & 2016 & Guidelines & Food Guidelines for the Argentine Population (update) \\
\hline & 2016 & Programme & Res. 732/16. Healthy Eating and Obesity Prevention Programme \\
\hline & 2018 & $\begin{array}{l}\text { Round-table } \\
\text { discussion }\end{array}$ & $\begin{array}{l}\text { Round-table discussion between the Health Minister and the Ministry of } \\
\text { Production and Work }\end{array}$ \\
\hline & 2019 & Plan & $\begin{array}{l}\text { National Plan for the Prevention of Overweight and Obesity in Children and } \\
\text { Adolescents }\end{array}$ \\
\hline \multirow[t]{8}{*}{ Brazil } & 2006 & Manual & $\begin{array}{l}\text { Obesity. Basic Care Notebooks, No. 12. Series A. Guidelines and Technical } \\
\text { Manuals }\end{array}$ \\
\hline & 2011 & Plan & $\begin{array}{l}\text { Strategic action plan to tackle chronic non-communicable diseases (CNCDs) in } \\
\text { Brazil }\end{array}$ \\
\hline & 2012 & Policy & National Food and Nutrition Policy \\
\hline & 2013 & Law & $\begin{array}{l}\text { Ordinance no. 424/GM/MS 2013. Redefines the guidelines for organising the } \\
\text { prevention and treatment of overweight and obesity as a priority line of care for the } \\
\text { Health Care Network for People with Chronic Diseases }\end{array}$ \\
\hline & 2104 & Manual & Obesity. Basic Care Notebooks, No. 38 \\
\hline & 2014 & Guide & Dietary Guidelines for the Brazilian Populat \\
\hline & 2014 & Strategy & $\begin{array}{l}\text { Intersectoral Strategy for Obesity Prevention and Control: recommendations for } \\
\text { states and municipalities }\end{array}$ \\
\hline & 2015 & Benchmark & A benchmark for monitoring food and nutrition in primary care \\
\hline
\end{tabular}

Source: author's own research.

Spain, concerned by the increase in the incidence of non-communicable chronic diseases, responded swiftly to the WHO mandate with its NAOS strategy (2005:10). Despite ranking in the middle of European countries in terms of its percentage of obese adults, it presents some high numbers for its child population, only surpassed by Italy, Malta and Greece. While NAOS stresses that 'an exhaustive understanding of the causes and their multiple, complex inter-relationships is essential for changing public habits and intervening in the causes of 
obesity' (2005:12), these essentially come down to two things: a) the sustained increase in sedentary lifestyles and b) the change in food patterns over the last 40 years from more to less healthy (Varela-Moreira et al., 2013). The rise of obesogenic environments has been blamed for these trends (NAOS, 2005:11) and has led to a series of proposals that 'encourage a decisive and sustained change towards a healthier diet and regular physical activity' (NAOS, 2005:19). Their aim is to reverse so-called 'unhealthy lifestyles' through multifaceted actions, proposing programmes that require the collaboration of numerous social actors and interventions in different spheres (school, work, family). Among other initiatives, food and nutrition labelling has been introduced; some voluntary agreements have been concluded with restaurants and industries; food vending machines been banned from schools; and an observatory has been set up to periodically quantify and analyse the prevalence of obesity and measure the progress made in preventing it. Though the measures are enacted from different spheres, when we analysed them as a whole, it was clear to see that there are limits to promoting the 'decisive and sustained change' advocated. For example, the food reformulation has been proposed as an initiative dependent on the good will of every food company for its successful implementation; and the government has opted, for now, not to tax so-called 'unhealthy' foods. It has, however, got on board with the European 'School Fruit, Vegetable and Milk Scheme', which aims to fund the free distribution of those items to schoolchildren from nursery to secondary school age.

Campaigns to prevent obesity have mainly been targeted at the general public and schoolage children in particular. They have largely focused on convincing schoolchildren (and their parents) of the positive benefits to be gained from adopting a 'healthy lifestyle'. Supported by health experts and educators, policy makers have created guides, workshops, games, audiovisual media, etc. that focus on changing behaviour by instructing people on what, when, where and how much to eat or to exercise. The NAOS motto is 'Come sano y muévete' (Eat healthy and get moving). The public's involvement in the creation of these 
measures amounts to appearing in the texts as the passive recipient of recommendations made by experts (also sports stars and celebrity chefs) that reinforce health discourses about appropriate or inappropriate foodways, and leisure and work. To these initiatives there have recently been added others targeted at children aged from three to six, with a gastronomic focus to inculcate the Mediterranean diet and, thus, 'improve their food culture'. Emerging from the Resolution on European Gastronomic Heritage, the programme 'El gusto es mío' (literally 'The pleasure is mine', but with a play on the Spanish word for taste) wants children not only to develop healthy habits, but also to learn in school to appreciate tastes, aromas and textures (PANGEI, 2015). In the world of work, there have been campaigns 'to be more active', promoting the idea of 'replacing coffee-breaks with walking-breaks', 'having work meetings while walking around', 'not sitting down for more than two hours at a time' or 'taking a break from sitting every 30 minutes' (PAAS, 2008).

In contrast to Spain, Argentina drew up its comprehensive strategy years later as healthcare had been focused on dealing with the problems associated with hunger and malnutrition in the wake of the 2001 crisis. Even so, obesity had already made it onto the agenda following the epidemiological surveys that were justifying its installation as an object of health policy from 2003/2005. In 2008 Law No. 26396 on Eating Disorders was promulgated, calling for the creation of a National Programme for the Prevention and Control of Eating Disorders, to include obesity along with bulimia and anorexia nervosa. With Resolution 1083/2009, obesity was now to be located within a National Strategy for the Prevention and Control of CNCDs and the Healthy Argentina National Plan. Up to that point, obesity had been considered a problem requiring specific care measures, beyond the Initiative for a Trans Fat Free Argentina (MS, 2016b), which - in contrast to Spain - legally stipulated restrictions on the content of trans fat acids in industrial food production. Finally, in 2016 the National Programme for Healthy Eating and Obesity Prevention (PNASPO) was set up. In 2017 the 
first plenary session of the National Commission on Healthy Eating was held, bringing together representatives of the WHO, NGOs and members of civil society.

Like NAOS in Spain, PNASPO conforms to WHO and PAHO directives. It also starts from a diagnosis of obesity and its economic impact, stating that 'overweight and obesity [are] related to unhealthy food and sedentary lifestyles...' (MS, 2016a:4) and '...the direct costs for the health system and the indirect ones for society are high... Obesity is associated with chronic illnesses and greater use of health system and other resources' (MS, 2016a:3). Its purpose is to offer an integrated focus on healthy eating and the problem of obesity, including the aspects determining its growth in the context of an obesogenic environment, which is also identified as bearing primary responsibility. According to the programme, this environment is expressed in the easy availability of food products with high salt content, saturated fats and free sugars; the existence of inappropriate advertising; the consumption of inadequate diets; and the lack of physical activity.

While, like NAOS, it proposes various courses of action such as better front-of-package labelling, or the promotion and regulation of the food supply through agreements with industry to reduce salt, trans fats and sugars, it basically moots interventions in individual behaviour through the promotion of a healthy diet and physical exercise at home, work or school (MS, 2019). So as in Spain, graphic materials are designed, involving depictions of a healthy meal, for example, or audiovisual recipes and games, or food guides pushing messages such as 'Eat rich, eat healthy', 'Your active break, add 30 minutes of physical activity every day', 'Up your intake of fruit, vegetables and fish' and 'Cut your intake of ultraprocessed foods'.

Recently, another initiative targeting the non-adult population has been added: the National Plan for the Prevention of Overweight and Obesity in Children and Adolescents (MS, 2019). This views 'obesity as an expression of malnutrition' within the framework of WHO and PAHO frameworks and thus seeks to treat 'those who suffer most from malnutrition in all its 
forms', with a rights and gender focus. While at the declarative level it seeks to upgrade food education and physical activity, reinforce nutritional quality, and promote sustainable food systems and the regulation of food products and environments (MS, 2019), its core activities have amounted to information and training of teachers and school canteen cooks. Guides, manuals and fun educational materials have also been produced for children, with messages such as 'eat in colour', 'eat a variety of fruit and veg', 'use your body every day', among others.

Finally, the Brazilian guidelines for organising actions to prevent obesity date back to the late 1990s with the definition of the National Food and Nutrition Policy (PNAN), revised in 2012 (Ministério da Saúde MS, 2012). As in Spain and Argentina, PNAN regards the decrease in physical activity and unhealthy eating patterns as the causes of obesity, likewise proposing actions in various sectors 'from the production to the final marketing of food and the securing of environments that facilitate changes in behaviour by individuals and society' (MS, 2012: 20). The problems of obesity are linked to the agroindustrial food systems, bringing the question of food sovereignty into the debate. At the same time, the individual is assigned responsibility for food choices, thus creating a need to 'invest in communication and health education tools and strategies to support health professionals' (MS, 2012: 23). A revised Dietary Guidelines for the Brazilian Population was published (MS, 2014a) and, in basic care, documents created (MS, 2006; MS, 2014b) to support professionals in the management of obesity. As happens in Argentina and Spain, intervention is individually focused through the promotion of a healthy diet and physical activity tailored to the life cycle with messages such as 'Do at least 30 minutes of physical activity every day', 'Keep your weight within healthy limits' (MS, 2014b: 95) and guidelines on shopping, food hygiene and storage.

In 2014, the Inter-ministerial Chamber of Food and Nutrition Security co-ordinated the formulation of the Intersectoral Plan to Combat Obesity, involving the design of a unique 
intersectoral strategy for states and municipalities by various ministries, civil society and members of the WHO/PAHO. This nexus was justified by the need for joint action by government and representatives of movements and organisations from different social sectors with the overarching aim of ensuring fulfilment of the right to food. One of the objectives of the strategy is to "promote appropriate and healthy eating and physical activity in the environment we inhabit' (CAISAN, 2014:13). As in the other countries, so-called obesogenic factors are deemed responsible for this trend, with their actions similarly focused on changing individual behaviour - above all by reducing the consumption of ultraprocessed products. The informational and educational activities seek to encourage selfcare and a culture of learning about food and nutrition. On top of that, the food guide and other learning materials contain messages to nudge changes in diet and physical activity: 'Base your diet on fresh or minimally processed foods', 'Avoid ultra-processed foods' and 'If you have cooking skills, try to develop and share them, especially with children and young people'.

In contrast to Spain and Argentina, the first line of action in the Brazilian strategy gives priority to 'facilitating the physical access of families and communities to food and traditional recipes and, on the other hand, to expanding the availability of suitable and healthy food in the country's public amenities' (CAISAN, 2014: 17). Thus, also proposed within the scope of this policy are integrated measures that seek to foster family farming, boost the consumption or regional foods and traditional dishes, and promote the replacement of ultraprocessed and processed foods with fruit and vegetables, whole grains or fish. The aim is to encourage smaller-scale marketing, taxes on food and inputs, and the institutional purchase of food produced by family farms through public appeals to philanthropic institutions (CAISAN, 2014). Finally, protocols have been drawn up for the comprehensive care of overweight and obese patients within the country's Unified Health System, and the 
Health Ministry has secured a Commitment Agreement with the associations representing the production sector to reduce the quantities of sugar, fat and salt in processed foods.

\subsection{Preventive measures and social distribution of obesity}

Although the documents make clear the need to prioritise initiatives targeted at groups with a higher prevalence of obesity, there are few programmes directed towards the most vulnerable or focused on gender. However, the epidemiological data indicates that obesity mainly affects sectors with the lowest income and/or educational level, and that within those it is in some cases more prevalent in women.

\section{Table 4}

Prevalence (\%) of overweight and obesity. Population, specific source of study and year in Spain, Argentina and Brazil.

\begin{tabular}{|c|c|c|c|c|c|c|}
\hline Country & Source & Year & Study population & $\begin{array}{l}\text { Excess } \\
\text { weight } \\
(\mathrm{S}+\mathrm{O})\end{array}$ & $\begin{array}{l}\text { Overweight } \\
\text { (S) }\end{array}$ & $\begin{array}{l}\text { Obesity } \\
\text { (O) }\end{array}$ \\
\hline \multirow[t]{3}{*}{ Spain } & \multirow{3}{*}{$\begin{array}{l}\text { ENSE (ENSE, } 2006 \\
2012 \text { and 2018) }\end{array}$} & 2006 & \multirow{3}{*}{$\begin{array}{l}\text { Population over } 18 \\
\text { years old }\end{array}$} & $48.7 \%$ & $33.2 \%$ & $15.5 \%$ \\
\hline & & $2011 / 2012$ & & $53.7 \%$ & $36.7 \%$ & $17 \%$ \\
\hline & & $2017 / 2018$ & & $54.4 \%$ & $36.9 \%$ & $17.5 \%$ \\
\hline \multirow[t]{4}{*}{ Argentina } & \multirow{4}{*}{$\begin{array}{l}\text { ENFR (MS, 2006, } \\
2009,2013,2018)\end{array}$} & 2005 & \multirow{4}{*}{$\begin{array}{l}\text { Population over } 18 \\
\text { years old }\end{array}$} & $49 \%$ & $34.4 \%$ & $14.6 \%$ \\
\hline & & 2009 & & $53.4 \%$ & $35.4 \%$ & $18 \%$ \\
\hline & & 2013 & & $57.9 \%$ & $37.1 \%$ & $20.8 \%$ \\
\hline & & 2018 & & $61.6 \%$ & $36.3 \%$ & $25.3 \%$ \\
\hline \multirow[t]{4}{*}{ Brazil } & \multirow{2}{*}{$\begin{array}{l}\text { POF (IBGE, } 2004 \\
\text { and 2011) }\end{array}$} & $2002 / 2003$ & \multirow{4}{*}{$\begin{array}{l}\text { Population over } 18 \\
\text { years old }\end{array}$} & $51.7 \%$ & $40 \%$ & $11.1 \%$ \\
\hline & & $2008 / 2009$ & & $63.8 \%$ & $49 \%$ & $14.8 \%$ \\
\hline & PNS (IBGE, 2014) & 2013 & & $77.7 \%$ & $56.9 \%$ & $20.8 \%$ \\
\hline & $\begin{array}{l}\text { VIGITEL } \\
\text { (MINISTERIO DA } \\
\text { SAÚDE, 2019) }\end{array}$ & 2018 & & $75.5 \%$ & $55.7 \%$ & $19.8 \%$ \\
\hline
\end{tabular}

Source: compiled by author using available data.

In Spain during the period analysed, there was a growing increase in excess weight. According to the Spanish National Health Survey (ENS), obesity went from 15.5\% in 2006 to $17.45 \%$ in 2017 . The data shows that it increased in both sexes, that it is greater with age, and that it is significantly higher among people with the lowest levels of income and educational attainment, especially women. Prevalence rises to $28.27 \%$ among people with no formal education, whereas it is down at $9.58 \%$ among university graduates. This difference is even more marked among uneducated women, $30.25 \%$ of whom are obese. A key epidemiological finding is that, over the period of the crisis, prevalence increased most 
rapidly among the most socially disadvantaged groups. Whereas in high-income sectors obesity even went down by one percentage point between 2006 and 2017 to stand at 9.29\%, over the same period it grew by three percentage points in low-income sectors, rising to $22.37 \%$. If we look at the differences by sex, obesity more than tripled in the case of the poorest women (23.98\%), as against $7.26 \%$ for the highest-earning group.

In Argentina, according to the 2018 National Survey of Risk Factors (ENFR), excess weight grew in all age groups, both sexes and all socioeconomic sectors, but comparison with previous surveys reveals that it increases with age, affects men more and is suffered most by people with lower income and educational levels. In the case of obesity specifically, it grew from 2005, reaching $25.3 \%$ in 2018 . While no significant differences were observed between males and females (26.6\% and $24.2 \%$, respectively), its frequency is significantly higher in the group with the lowest level of education compared with the group at the other end of the scale. It is likewise higher in the lowest-income groups (27.6\%) than in the topearning groups (19.6\%). In terms of progression, it has been increasing at a greater rate among lower-income groups: in 2005 , it was $16.3 \%$ in that sector, while among high earners it was $13.1 \%$; by 2018 these figures had grown to $27.6 \%$ and $19.6 \%$ respectively.

In Brazil, the course of obesity has been reconstructed using different types of survey with disparate methodologies. The Family Budget Survey (POF) shows that the prevalence of obesity went from $11.1 \%$ in $2002-2003$ to $14.8 \%$ in $2008-2009$, going up with age and proving higher among the less educated. Despite overweight being more common among men, it is women who present most with cases of obesity, $20.7 \%$ as against $18.7 \%$. For its part, the 2013 National Health Survey (PNS) points to a continuous increase in overweight and obesity (to $56.9 \%$ and $20.8 \%$ respectively) and shows that the latter has multiplied sixfold among men and tripled among women, reaching $16.9 \%$ and $24.1 \%$ respectively. Finally, the VIGITEL data from 2018 presents a steady rise in the frequency of overweight (55.7\%) and obesity (19.8\%) compared with the POF figures for 2002-2003 and 2008-2009, 
and a slight downward trend compared with the PNS ones for 2013. The same 2018 VIGITEL data also reveals that the frequency of obesity in both sexes goes down inversely to educational level, but especially for women.

This unequal distribution of obesity has been considered to a very modest extent in the strategies analysed, and more discursively than in the form of specific interventions. This contrasts with the fact that the primary regulations refer, albeit briefly, to the need to 'act on the underlying economic, physical and social conditions that create and determine health' (PAAS, 2008:7). As previously stated (Gracia-Arnaiz, 2017), the Food Safety and Nutrition Law of 2011, passed at the height of the crisis in Spain, notes in passing that obesity mainly affects the most socially disadvantaged classes and indicates that the NAOS strategy should therefore prioritise measures targeting those groups (Law 17/2011:6). That same year, the Evaluation and Monitoring of the NAOS Strategy (Ballesteros et al., 2011) was published, a specific tool for evaluating all the actions realised that uses, among other things, gender and social class indicators; and in 2013 the Observation Centre for Nutrition and the Study of Obesity was set up, its responsibilities to include detecting changes in the prevalence of obesity in response to social inequalities and environmental factors.

Although post-2015, following the reorientation of public policy resulting from the European Food and Nutrition Action Plan 2015-2020 (WHO-EU, 2014), some programmes have targeted people at the lower end of the socioeconomic scale, they have adopted similar approaches, mainly directed at changing behaviour. One example is the POIBA project (2010-14) devised by the Barcelona Public Health Agency for children aged 11-12, half of whom live in the poorest barrios of the city (Ariza et al., 2014). This programme aims to promote physical activity and healthy eating through educational workshops and recreational activities involving teachers, children and their families. An initial evaluation of the programme's efficacy revealed positive changes and a short-term decrease in the 
obesity rate. However, they were larger and of longer duration among children from wealthier areas (Sánchez-Martínez et al., 2016).

Something similar is happening in Argentina. Despite a recognition of the increased prevalence of obesity throughout the whole population, but especially in the least privileged sectors, as well as the role played by environments and food systems, specific measures tend to disregard the social distribution of obesity. Although in 2015 the Project for Protecting Vulnerable People against CNCDs began to be implemented, its activities have again focused on the promotion of physical activity and healthy eating. Here also the measures are directed at changing behaviour, even in socially disadvantaged sectors (MS, 2015). This is reinforced in the same messages: one ministry of health audiovisual resource does acknowledge that healthy eating depends on multiple factors, including the price of food, but also asserts that 'you can improve your diet within any budget' (MS, 2017). Another ministerial recommendation in the context of precarious food situations suggests that people should 'prefer home-made food, it's healthier and cheaper' (MS, 2017). Beyond these communicative efforts in the health sector, other steps have been taken to curb the increase in basic food prices in high inflation contexts such as suffered by Argentina - removing VAT on basic shopping-basket items, for example, and the Watchlist Prices or Essential Prices Programme, which includes a list of products with fixed prices (e.g. oils, pasta, wheat and corn flours, milk, yogurts and desserts, preserves, sugar, biscuits, yerba and jams). However, foodstuffs considered healthy are excluded, contrary to health policies.

In Brazil, the specific policies for tackling obesity have also focused on individualised measures that take little account of the unequal distribution of obesity. There have been strategies in the state schools with projects such as 'Educating with the school garden' or state laws regulating the food sold and marketed in these spaces. In basic healthcare, income only features in consultations with the nutritionist and the subsidising of diet plan prescriptions. However, the Food and Nutritional Security policies have emphasised access, 
food production and the promotion of family farming among the most vulnerable groups. Within the scope of the National School Food Programme, the application of at least 30\% of budget to the acquisition of food from such sources is one of the greatest advances in terms of establishing criteria to achieve social impacts for public procurement. This emphasis has penetrated the debate on the definition of 'adequate and healthy food' in relation to obesity, signalling the importance of public policies and regulatory actions to secure it. Nevertheless, such co-ordination is still presented as a huge challenge, even more so given the current austerity policies and the dismantling of previous programmes by the current government. On the other hand, the Food Guide (2014) indicates that the information is useful for those suffering from specific diseases regardless of social class or gender, as like all such guides it is aimed at the general population. Even so, the emphasis must remain on food as a basic human right conditioned by dimensions of gender, race and ethnicity, requiring physical and financial accessibility.

\section{Discussion and conclusion}

In culturally distinct but epidemiologically similar contexts, the three countries have been active in establishing policies to tackle obesity and have done so following WHO, EU and PAHO guidelines. Despite this, none of them has managed to reverse the trend. In the case of Argentina and Brazil, it has even grown at a faster rate than in previous phases, actually coinciding with the implementation of preventive actions. Although the typology of the programmes proposed in the three countries has been varied, it is less plural in terms of its nature and scope. The reasons are to be found, for one part, in the type of diagnosis constructed and the excessive emphasis placed on individual responsibility. The causes are related to profound changes in diet and physical activity, and the solutions directed towards 
changing lifestyles. It is, however, an imprecise diagnosis and the measures are, to say the least, insufficient.

Most of the programmes focus on promoting a standardised model of diet and physical exercise - and thus individual self-control, indicating what and how much people should eat or move. Among the solutions proposed, the need for better nutritional education to improve food habits features prominently. Attempts to improve lifestyles take the form of programmes aimed at educating the public (particularly children) but often fail to take into account the social nature of eating and health (Delormier et al., 2009). There is scant reference in the texts to people's lived experience (including that of obese people) or how and why they eat what they do. People are routinely labelled as 'target groups' requiring 'intervention' (GraciaArnaiz, 2017). With the occasional exception, project targets are seen as simple recipients of proposals legitimised by experts - as people who need to be taught healthier choices, and not as individuals with the skills and knowledge to manage their own lives and resources. Recommendations about 'ideal' eating, cooking, drinking and exercise patterns seem to be based on the premise that those receiving these messages are groups or communities as homogenous as 'average consumers' (Monaghan et al. 2013). The implicit conception postulates a 'person' who is free to choose and rational in their decisions. However, these subjects are socially and culturally conditioned. Food choices are neither individual nor rationally straightforward, and it is necessary to work out the reasons why people act to the detriment of their own health despite being aware of the consequences. We know that neither the accumulation nor the understanding of nutritional knowledge necessarily changes food habits (Fischler and Masson, 2008). The answer is therefore to be found in the fact that the daily demands on many people do not allow for a more balanced and comfortable lifestyle, making it clear that in many cases a change of life is necessary for a change of diet - and that is not always easy or possible. For many, the lack of resources is the main reason. 
To be precise, one of the consequences of the economic crisis and the austerity policies that accompanied it has been the increase of precarisation in the three countries, which has made access to safe and healthy food difficult among the most socially vulnerable. In the European context, Spain stands out as being one of the countries where social inequality has grown most in the last decade and where work has become more precarious. Since the beginning of the global economic crisis in 2008 , living conditions have changed significantly. The government responded to the initial effects of economic recession by focusing its efforts on bank bailouts, liberalising labour regulations, reducing health spending and increasing direct and indirect taxes (Navarro, 2015). Although some macroeconomic indicators have improved since 2015 and, according to the Active Population Survey (EPA 2018), the unemployment rate fell to $16.55 \%$ in the fourth quarter of 2017 , the number of unemployed is still nearly 3.5 million people. Additionally, the quality of jobs has worsened, with more temporary contracts and lower wages, which do not allow many workers to lift themselves out of poverty (Fernández, 2017). Both poverty and income inequality are among the highest in the European Union. According to the AROPE index, the proportion of Spain's population at risk of social exclusion increased from $23.3 \%$ in 2007 to $26.1 . \%$ in 2018 , and currently affects 12.3 million people (Llanos Ortiz, 2017), many of whom depend on social assistance for basic needs (Caritas 2016).

In Argentina, following the recovery from the 2001 crisis, the situation worsened again with the international financial crisis and from 2015 the adoption of a neoliberal model to negotiate the local, regional and international economic problems. With fiscal and monetary tightening policies, inflation became widespread $(52.1 \%$ variations in food prices for 2018/2019 according to INDEC, 2019a) and was not accompanied by adjustments in income, affecting purchasing power and social inequality. Thus, the percentage of people in poverty went up from 31\% in 2006 to 35.4\% in 2019 (INDEC, 2019b), and the unemployment rate from $8.7 \%$ in 2006 to $10.6 \%$ in 2019 (INDEC, 2019c). This has had a profound effect 
on access to food (both quantity and quality) in the least advantaged sectors, with the data confirming that food insecurity (the difficulty of accessing food in sufficient quantity and quality for economic reasons) affected $22.2 \%$ of the urban population in 2019 , and within that $9.3 \%$ experienced actual hunger (ODSA-UCA, 2019).

In the case of Brazil, poverty has been a constitutive part of its history, stemming from a situation of social inequality due to a long political trajectory privileging the strong concentration of income over decades. However, as a result of investment in policies to overcome poverty and malnutrition, the period 2001 to 2014 saw a marked and historic reduction in inequality. Even so, a critical phase began at the end of that year due to unemployment, a fall in average incomes, the growth of inequality and a consequent rise in poverty again. From the end of 2014 to the end of 2017 , it increased by $33 \%$, affecting almost 55 million people (Neri, 2019). This rising poverty combines with the country's lack of social security networks accentuated by a political and economic crisis along with a series of austerity measures that have, for example, frozen investments in key areas such as health, education and social security reforms - and more directly in food and nutritional security, with the abolition of the National Council for Food and Nutritional Security. If up to 2014 inter-governmental policies succeeded in taking Brazil off the hunger map, current policies have put it back on again. As in Argentina, there is a growing recognition of malnutrition and obesity as different expressions of food and nutrition insecurity, with an implied assumption of their close interrelationship (Swinburn et al., 2019).

Thus, bearing in mind that international health agencies and governments recognise 'the complex interactions between personal choices, social norms and economic and environmental factors' (WHO, 2004:9), and the need to take into account 'local cultural and socioeconomic circumstances' and 'social determinants for reducing inequality in the distribution of obesity' (WHO-EU, 2014:2), it is worth asking why studies were not first 
carried out on the complex nature of those interactions, exploring the local manifestations of the problem and proposing actions to transform adverse contexts on that basis.

To date, the necessary efforts have not been made to understand how so-called 'environmental factors' might have influenced social practices in general and eating habits in particular, or whether these influences have necessarily had a negative impact on the health of all to the same degree. Or at least the efforts made have not reflected the epidemiological data. Viewed as a whole, the programmes have taken up the quick-fix global slogans, since 'raising awareness', 'promoting', 'encouraging', 'stimulating' healthy lifestyles is evidently easier than transforming structural factors beyond the diet/exercise axis or the weight of variables such as social class or gender. So far, they have served to demand responsibilities of the various social actors involved, while leaving it up to these subjects to make the ultimate decision to 'choose' how to protect or put their health at risk according to their life chances. The options available are, however, subject to the effects of state economic policies that have, judging by the growing precariousness of a significant part of the population, acted counter to them.

In general, the responses have been formulated without further research into the different dimensions of obesity, either because they have been short-term, not based on diagnoses adjusted to each context, or coincided with the dismantling of previous policies that, as in the case of Brazil, had responded in an integrated manner to the various expressions of malnutrition, and in particular hunger. Some very recent initiatives can be taken as examples in this direction. Such is the case with the studies carried out in Brazil on the food environment from the point of view of access to healthy and sustainable food, which are mapping places and relating them to income levels in order to influence public policy (Backes et al., 2019; Camargo et al., 2019), or the research currently being carried out in Argentina with Health Ministry funding on obesogenic environments in socially vulnerable 
situations (CISPAN, FIC and PN, 2019). We will have to wait and see which measures are implemented once these determinants are identified and what the results are.

\section{Note}

${ }^{1}$ Include project data

\section{Declarations}

Ethics approval and consent to participate, "Not applicable"

Consent for publication, "Not applicable"

Availability of data and materials, "Data sharing is not applicable to this article as no datasets were generated or analysed during the current study"

Competing interests, "'The authors declare that they have no competing interests"'

Funding: This work was supported by Ministerio de Economía y Competitividad, Spain [grant number (enter research data)].

Authors' contributions: MGA participated in the study design and conception. All authors participated data collection, and analysis and helped in drafting article preparation for publication and critically reviewed the manuscript for intellectual content. All authors have read and approved the final manuscript.

Acknowledgements, "Not applicable"

\section{References}

Ariza, C et al. La prevención de la obesidad infantil desde una perspectiva comunitaria. Atención Primaria, 2014; 47 (4): 246-255.

Backes V, Bairros F, Cafruni CB, Cummins S, Shareck M, Mason K et al. Food environment, income and obesity: a multilevel analysis of a reality of women in Southern Brazil. Cad. Saúde Pública. 2019; doi: /10.1590/0102-311×00144618. 
Ballesteros $\mathrm{J}$ et al. Evaluación y seguimiento de la Estrategia NAOS: conjunto mínimo de indicadores. Madrid, España: Ministerio de Sanidad, Política Social e Igualdad; 2011.

Bray, G, Tartaglia L. Medicinal strategies in the treatment of obesity. Nature, 2000; doi: $10.1038 / 35007544$.

Brownell K, Horgen K. Food fight. EEUU: McGraw Hill Professional; 2003.

Câmara Interministerial De Segurança Alimentar E Nutricional (CAISAN). Estratégia Intersetorial de Prevenção e Controle da Obesidade: recomendações para estados e municípios. Brasília, Brasil: CAISAN; 2014.

Camargo D, Belon A, Marín-León L, Souza BF, Pérez-Escamilla R, Segall-Corrêa A. Comparing food environment and food purchase in areas with low and high prevalence of obesity: data from a mapping, in-store audit, and population-based survey. Cad. Saúde Pública. 2019; doi: 10.1590/0102-311x00247218.

Campbell D. Anthropology's contribution to public health policy development. McGill J. Med.: MJM. 2011; 13 (1), 76.

Cáritas Española. Memoria 2016. 2016. https://www.caritas.es/memoria2016/. Accessed 15 Jan 2017.

CISPAN, FIC, Programa Nutricional de la Ciudad de Buenos Aires. Estudio multicêntrico sobre Entornos Obesogénicos en situaciones de vulnerabilidad. Presentación de resultados. Ciudad de Buenos Aires; 2019.

Delormier, $\mathrm{T}$ et al. Food and eating as social practice -understanding eating patterns as social phenomena and implications for public health. Sociology of Health \& Ilness. 2019; doi: 10.1111/j.1467-9566.2008.01128.x.

Dinsa G. Obesity and socioeconomic status in developing countries: a systematic review. Obes. Rev.; 2012, doi: 10.1111/j.1467-789X.2012.01017.x. 
ENS.

Encuesta

Nacional

de

Salud.

2006

http://www.msssi.gob.es/estadEstudios/estadisticas/encuestaNacional/encuesta2006.ht m Accessed 15 Jan 2017.

ENS. Encuesta Nacional de 2011-2012. http://www.msssi.gob.es/estadEstudios/estadisticas/encuestaNacional/encuesta2011.ht m Accessed 15 Jan 2017.

$\begin{array}{llll}\text { ENS, } & \text { Encuesta } & \text { Nacional }\end{array}$ http://www.msssi.gob.es/estadEstudios/estadisticas/encuestaNacional/encuesta2018.ht m Accessed 15 Jan 2017.

Fernández D. Los salarios en la recuperación española. Cuadernos de Información Económica. 2017; 260: 1-12.

Fischler C, Masson E. Manger. Français, Européens et Américains face à l'Alimentation. París, Odeile Jacob; 2008.

(Anonymized)

Guest G. Applied Thematic Analysis. California, EEUU: Sage Publications; 2012.

Hernáez Á, Zomeño MD, Dégano IR, Pérez-Fernández S, Goday A, Vila J, Civeira F, Moure R, Marrugat J. Excess Weight in Spain: Current Situation, Projections for 2030, and Estimated Direct Extra Cost for the Spanish Health System. 2016; doi: 10.1016/j.rec.2018.10.010.

Instituto Brasileiro de Geografia E Estatística (IBGE). Pesquisa de Orçamentos Familiares 2002-2003: análise da disponibilidade domiciliar de alimentos e do estado nutricional no Brasil. Rio de Janeiro, Brasil: IBGE; 2004. 
Instituto Brasileiro de Geografia E Estatística (IBGE). Pesquisa de Orçamento Familiares 208-2009: Análise do consumo alimentar pessoal no Brasil. Rio de Janeiro, Brasil: IBGE; 2011.

Instituto Brasileiro de Geografia E Estatística (IBGE). Pesquisa Nacional de Saúde, 2013. Rio de Janeiro, Brasil: IBGE, 2014.

Instituto Nacional de Estadísticas y Censos (INDEC). Estadísticas sobre trabajo e ingresos, Argentina. 2019. https://www.indec.gob.ar/indec/web/Nivel3-Tema-4-31 Accessed 15 Jan 2017.

Instituto Nacional de Estadísticas y Censos (INDEC). Estadísticas sobre canasta básica alimentaria, Argentina. 2019. https://www.indec.gob.ar/indec/web/Nivel4-Tema-4-43-149 Accessed 15 Jan 2017.

Instituto Nacional de Estadísticas y Censos (INDEC). Estadísticas sobre pobreza, Argentina. 2019. https://www.indec.gob.ar/indec/web/Nivel3-Tema-4-46 Accessed 15 Jan 2017.

Jiwani SS, et. al. The shift of obesity burden by socioeconomic status between 1998 and 2017 in Latin America and the Caribbean: a cross-sectional series study. Lancet Glob Health. 2019; doi: 10.1016/S2214-109X (19)30421-8

Kleinman, J. The Illness Narratives. New York, EEUU: Basic Books; 1988.

Llanos Ortiz JC. El estado de la pobreza seguimiento del indicador de riesgo de pobreza y exclusión social en España 2008-2016, Madrid: EAPN España; 2017.

Ministerio de Salud (MS). Plan Nacional de Alimentación Saludable en la Infancia y Adolescencia para la Prevención del Sobrepeso y la Obesidad en Niños, Niñas y Adolescentes- Plan Así. Buenos Aires, Argentina: MS; 2019. 
Ministerio de Salud (MS). Cuarta Encuesta Nacional de Factores de Riesgo para Enfermedades No Transmisibles. Buenos Aires, Argentina: MS; 2018.

Ministerio de Salud. Sobrepeso y Obesidad en Argentina. 2017. https://www.youtube.com/watch?time continue $=60 \& v=0 z T 0 t X r e 8 \mathrm{Jw}$ Accessed 15 Jan 2017.

Ministerio de Salud. Programa Nacional de Alimentación Saludable y Prevención de la Obesidad. Res.732/16. Buenos Aires, Argentina: MS; 2016a.

Ministerio de Salud. Boletín de vigilancia de Enfermedades No Transmisibles y Factores de Riesgo. Buenos Aires, Argentina: MS; 2016b.

Ministerio de Salud. Guías Alimentarias para la Población Argentina. Buenos Aires, Argentina: MS. 2016c.

Ministerio de Salud. Proyecto de Protección de la población vulnerable contra las enfermedades crónicas no transmisibles. Buenos Aires, Argentina: MS; 2015.

Ministerio de Salud. Tercera Encuesta Nacional de Factores de Riesgo para Enfermedades No Transmisibles. Buenos Aires, Argentina: MS; 2013.

Ministerio de Salud. Segunda Encuesta Nacional de Factores de Riesgo para Enfermedades No Transmisibles. Buenos Aires, Argentina: MS; 2011.

Ministerio de Salud. Estrategia Nacional para la Prevención y Control de Enfermedades No Transmisibles y Plan Nacional Argentina Saludable. Res. 1083/2009. Buenos Aires, Argentina: MS; 2009.

Ministerio de Salud. Primera Encuesta Nacional de Factores de Riesgo para Enfermedades No Transmisibles. Buenos Aires, Argentina: MS; 2006.

Ministério da Saúde (MS). Política Nacional de Alimentação e Nutrição. Brasília, Brasil: MS; 2012. 
Ministério da Saúde (MS). Guia alimentar para a população brasileira. Brasília, Brasil: MS; 2014a.

Ministério da Saúde (MS). Estratégias para o cuidado da pessoa com doença crônica: obesidade. Brasília: Ministério da Saúde; 2014b.

Ministério da Saúde. VIGITEL. Brasil 2018: Vigilância de fatores de risco e proteção para doenças crônicas por inquérito telefônico. Brasília: MS; 2019.

Monagahn LF, Colls R, Evans B. Obesity discourse and fat politics: research, critique and interventions. Critical Public Health. 2013; doi: 10.1080/09581596.2013.814312

NAOS. Estrategia para la Nutrición. Actividad Física y Prevención de la Obesidad. Madrid, España: Agencia Española de Seguridad Alimentaria; 2005.

$\begin{array}{llllll}\text { NAOS. } & 10 & \text { Años } & \text { estrategia } & \text { NAOS. } & 2015 .\end{array}$ http://www.aecosan.msssi.gob.es/AECOSAN/docs/documentos/nutricion/Teresa_Roble do_10_anyos_ESTRATEGIA_NAOS_octubre2015.pdf Accessed 15 Jan 2017.

Navarro V. Ataque a la democracia y al bienestar. Barcelona: Anagrama; 2015.

Neri M. A escalada da desigualdade: qual foi o impacto da crise sobre a distribuição de renda e a pobreza?, Rio de Janeiro, RJ. FGV Social; 2019.

$\mathrm{Ng} \mathrm{M}$ et al. Global, regional, and national prevalence of overweight and obesity in children and adults during 1980-2013: a systematic analysis for the Global Burden of Disease Study 2013. Lancet. 2014; doi: 10.1016/S0140-6736(14)60460-8.

ODSA-UCA Incidencia de la inseguridad alimentaria severa y total para los Hogares y la Población en la Argentina urbana 2010-2019. Buenos Aires: ODSA-UCA. 2019; http://wadmin.uca.edu.ar/public/ckeditor/Observatorio\%20Deuda\%20Social/Presentacio nes/2019/2019-OBSERVATORIO-INSEGURIDAD-ALIMENTARIA-SEVERA-Y-TOTALVF.pdf Accessed 15 Jan 2017. 
OPS. Estrategia Regional y Plan de Acción para un Enfoque Integrado Sobre la Prevención y el Control de las Enfermedades Crónicas. Washington DC: OPS; 2007.

OPS. Plan de acción para la prevención y el control de las enfermedades no transmisibles en las Américas 2013-2019. Washington DC: OPS; 2014.

OPS. Políticas y programas alimentarios para prevenir el sobrepeso y la obesidad. Lecciones aprendidas. Washington, EEUU: FAO/OPS; 2018.

PAAS. Pla Integral per a la promoció de la salut mitjançant l'activiat física i l'alimentació saludable. Barcelona: Generalitat de Catalunya; 2008.

PANGEI. Programa de alimentación, nutrición y gastronomía para educación infantil. EI gusto es mçio. Madrid: Subdirección General de Documentación y Publicaciones y AECOSAN; 2015.

Popkin BM, Gordon-Larsen P. The nutrition transition: worldwide obesity dynamics and their determinants. Int. J. Obes. 2004; doi: 10.1038/sj.ijo.0802804.

Sánchez-Martinez F et al. Factores asociados al sobrepeso y la obesidad en escolares de 8 a 9 años de Barcelona. Rev. Esp. Salud Publica. 2016; 90: e40027. http://scielo.isciii.es/scielo.php?script=sci arttext\&pid=S1135$\underline{57272016000100428 \& \operatorname{lng}=e s}$. Accessed 15 Jan 2017.

Swinburn BA et al. The Global Syndemic of Obesity, Undernutrition, and Climate Change: The Lancet Commission report, Lancet. 2019; doi: 10.1016/

Swinburn BA et al. Dissecting obesogenic environments: the development and application of a framework for identifying and prioritizing environmental interventions for obesity. Prev. Med. 1999; doi: 10.1006/pmed.1999.0585.

Varela-Moreiras $G$ et al. Obesidad y sedentarismo en el siglo XXI: ¿qué se puede y debe hacer?. Nutr. Hosp. 2013; 28 (5), 1-12. 
WHO. Obesity: preventing and managing the global epidemic (Report of a WHO Consultation) Geneva, (WHO technical report series 894); 2000.

WHO. The Global Strategy on Diet, Physical Activity and Health. Washington: WHO; 2004.

WHO. Population-based approaches to Childhood obesity prevention. Geneve: WHO Library Cataloguing-in-Publication Data; 2012.

WHO-UE. WHO European Region Food and Nutrition Action Plan 2014-2020. Copenhaguen: WHO Regional Office for Europe; 2013.

WHO-EU. Obesity and inequalities, Copenhagen: WHO Regional Office for Europe; 2014.

WHO-EU. Using price policies to promote healthier diets. 2015. http://www.euro.who.int/ data/assets/pdf file/0008/273662/Using-price-policies-topromote-healthier-diets.pdf Accessed 15 Jan 2017.

WHO. FEED cities Project. The food environment description in cities in Eastern Europe and Central Asia. Moldova: WHO; 2017.

WHO. Mapping the health system response to childhood obesity in the WHO European Region. An overview and country perspectives; 2019.

http://www.euro.who.int/ data/assets/pdf file/0019/401176/Childhood-obesityweb.pdf?ua=1 Accessed 15 Jan 2017. 